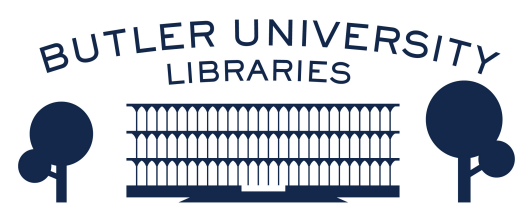

Journal of Hindu-Christian Studies

Volume 13

Article 12

January 2000

\title{
Tributes: Wilhelm Halbfass
}

Francis X. Clooney

Follow this and additional works at: https://digitalcommons.butler.edu/jhcs

Part of the Religion Commons

\section{Recommended Citation}

Clooney, Francis X. (2000) "Tributes: Wilhelm Halbfass," Journal of Hindu-Christian Studies: Vol. 13, Article 12.

Available at: https://doi.org/10.7825/2164-6279.1232

The Journal of Hindu-Christian Studies is a publication of the Society for Hindu-Christian Studies. The digital version is made available by Digital Commons @ Butler University. For questions about the Journal or the Society, please contact cbauman@butler.edu. For more information about Digital Commons @ Butler University, please contact digitalscholarship@butler.edu. 


\section{TRIBUTES}

\section{Wilhelm Halbfass - An Appreciation by Francis X. Clooney}

\begin{abstract}
WILHELM HALBFASS, PROFESSOR of Indian Philosophy in Asian and Middle Eastern Studies and South Asia Regional Studies at the University of Pennsylvania, died 25 May 2000 after suffering a brain hemorrhage and lapsing into a coma on 23 May. Dr Halbfass had just turned 60 years old. He had been on the faculty at Penn since 1973, when he came as a visiting lecturer and then became an associate professor the following year. He was promoted to full professor in 1982. The author of six books, numerous articles, encyclopedia entries, and book reviews, in 1997 his work was recognized by 25 colleagues and former students in Beyond Orientalism: The Work of Wilhelm Halbfass and its Impact on Indian and Cross-Cultural Studies, edited by E. Franco and K. Preisendanz. His responses to each of the essays in this 650-page volume are typical of his conscientious, courteous, and meticulous scholarship.

While Wilhelm Halbfass did not characterize his work as theology or engage formally in interreligious dialogue, his
\end{abstract}

scholarship has been enormously helpful in the field of Hindu-Christian studies. He ably retrieved and situated the works of Sankara, offered important insights into the hermeneutics of the Mimamsa tradition, analysed traditional Indian views of religious diversity, and retrieved for contemporary reflection the difficult and somewhat obscure work of the Vaisesika school. His masterful Indien und Europa: Perspektiven ihrer geistigen Begegnung, revised and published in English as India and Europe: An Essay in Understanding, provided a rich and insightful analysis of the history of the interactions of Indians and Westerners, Hindus and Christians, and can be justly recognized as one of the normative defining works for the field of Hindu-Christian studies.

He is survived by his wife, Helga, his two daughters, his parents, and a brother. $\mathrm{He}$ will be sorely missed by all those who read his works, by his colleagues and students, and by all of us who have met this formidable and gentle scholar.

\section{Sara Grant, RSCJ-An Appreciation by Bradley J. Malkovsky}

SARA GRANT WAS a Catholic nun (RSCJ), originally from Scotland, who lived in India since the 1950s. She was a professor of Indian thought both in Bombay and Poona, and spent many years as co-acarya of the Christa Prema Seva Ashram in Poona. Her specialty was Sankara and Sankara's significance for Christian theology and spirituality. She counted Richard De Smet and Swami Abhishiktananda among her closest friends. Her spiritual and intellectual autobiography, Towards an Alternative Theology: Confessions of a Non-Dualist Christian (Bangalore: Asian Trading, 1991), originally the Teape Lectures delivered at the University of Cambridge in 1989 , will be re-appearing from the University of Notre Dame Press (Indiana, USA) within a year or two. Her dissertation on the role of relation in Sankara appeared recently in India. In 1993 she received the Ba-Bapu Puraskar Prize by Gandhians in Pune (the first year it was awarded) for a life exemplifying the precepts and ideals of the Mahatma. Two years later the All-India Association for Christian Higher Education conferred upon her its eminent Ecumenical Educator Award in recognition of her efforts in promoting intercultural and interreligious understanding. 